\title{
Pisanie Herberta. \\ O (i wokół) nowej biografii autorstwa Andrzeja Franaszka
}

Mateusz Antoniuk

TEKSTY DRUGIE 2019, NR 1, S. 138-164

DOI: 10.18318/td.2019.1.9 | ORCID: 0000-0002-1608-2691

$\mathbf{O}$ publikowana w połowie roku 2018 nakładem wydawnictwa „Znak” książka Andrzeja Franaszka Herbert. Biografia nie jest pierwszą próbą budowania opowieści o, określmy to nieco po staroświecku, życiu i twórczości autora Raportu z oblężonego Miasta. Komponent biograficzny zawierały dawniejsze, klasyczne już monografie Herbertowskiego dzieła', w roku 2001 ukazała się znakomita książka Jacka Łukasiewicza², będąca syntetycznym, popularyzatorskim ujęciem twórczości poety na tle biograficznym, rok później miała premierę „biografia reportażowa” autorstwa Joanny Siedleckiej;

1 Zob. S. Barańczak Uciekinier z Utopii: o poezji Zbigniewa Herberta, wyd. I., Polonia Book Fund, Londyn 1984; A. Kaliszewski, Gry pana Cogito, wyd. I, Wydawnictwo Literackie, Kraków 1982.

2 J. Łukasiewicz Herbert, Wrocław 2001.

3 J. Siedlecka Pan od poezji: o Zbigniewie Herbercie, Prószyński i S-ka, Warszawa 2002 (wyd. II zmienione 2018).

\section{Mateusz Antoniuk}

- dr hab., literaturoznawca, pracuje na Wydziale Polonistyki UJ. Ostatnio publikowane książki: Pracownia Herberta. Studia nad procesem tekstotwórczym (2017, współautorstwo i redakcja); Słowo raz obudzone. Poezja Czesława Miłosza: próby czytania (2015). Publikował m.in.

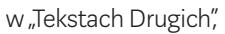
„Ruchu Literackim”, „Przestrzeniach Teorii", „Textual Cultures". Zainteresowania: literatura polska XX wieku, krytyka genetyczna. Kontakt: mateusz.antoniuk@ uj.edu.pl 
istnieje także „biografia rodzinna” autorstwa Rafała Żebrowskiego4, poświęcona wczesnemu okresowi życia artysty. Równocześnie z pracą Franaszka ukazała się biografia napisana przez Brigitte Gautier - opublikowana w języku francuskim, we Francji, do francuskiego czytelnika, przede wszystkim, adresowana ${ }^{5}$.

Herbert Andrzeja Franaszka wszelako, nie będąc przedsięwzięciem całkowicie pionierskim, jest znaczącym wydarzeniem w zakresie polskiego pisarstwa biograficznego i historycznoliterackiego, jawi się jako pozycja ważna i wyrazista. Trzy są przynajmniej po temu powody.

Po pierwsze, uwagę przykuwają już „parametry techniczne”. Opowieść o życiu artysty urodzonego w roku 1924, zmarłego w roku 1998, wraz z wkomponowanym w nią wątkiem interpretacji kolejnych tomów wierszy, utworów prozatorskich, dramatów (i, co ewidentnie ważne dla Franaszka, z zarysowaniem historii ich krytycznoliterackiej recepcji w Polsce i poza Polską) mieści się w dwu woluminach (pierwszy nosi podtytuł Niepokój, drugi opatrzony został formułą Pan Cogito), co przekłada się na, łącznie, stron 1818. Po drugie, ta obszerna książka imponuje skalą wykonanej pracy badawczej, przede wszystkim zaś - zakresem kwerendy archiwalnej. Andrzej Franaszek bazuje na wieloletnich badaniach, prowadzonych w ogromnym archiwum Zbigniewa Herberta zdeponowanym w Bibliotece Narodowej w Warszawie oraz w mniejszych zbiorach "dokumentów Herbertowskich", znajdujących się w pieczy innych instytucji. Ale nie tylko: w książce znajdziemy odniesienia do kilkudziesięciu, prywatnych i państwowych kolekcji archiwalnych, rozsianych po Polsce, Europie Zachodniej i Stanach Zjednoczonych. Archiwa dokumentujące pracę ludzi oraz instytucji, z którymi Herbert spotykał się, krócej lub dłużej współpracował, tworzą swoistą sieć, za pomocą której Franaszek usiłuje pochwycić (stale umykającą) materię życia. I jest wreszcie trzeci powód, dla którego książka Andrzeja Franaszka może być określona mianem ważnej - ten mianowicie, że budzi ona rozmaite opinie i reakcje, więcej: rozmaite emocje. Właściwie było to do przewidzenia, nim jeszcze książka zdążyła się ukazać. Z biografiami wybitnych, sławnych pisarzy jest po trosze jak z ekranizacjami kanonicznych powieści - czytelnicy-widzowie noszą w sobie różne wizualizacje (konkretyzacje, powiedzielibyśmy "starym” językiem) sytuacji i bohaterów, trudno o konsensus, które wątki fabularne

4 R. Żebrowski Zbigniew Herbert: „Kamień, na którym mnie urodzono”, Państwowy Instytut Wydawniczy, Warszawa 2011.

5 B. Gautier La poésie contre le chaos, Noir sur Blanc, Paris 2018. 
można umniejszyć, które zaś winny być oddane w skali 1:1. Tak i z opisem życia poety: można w nieskończoność spierać się o właściwe, wewnętrzne proporcje biografii, która przecież, jako opowieść scalająca i interpretująca, coś z materii życia musi eksponować, coś zaś przesuwać na plan dalszy; biograf nieustannie oscyluje między metabiograficznymi tropami hiperboli i litoty. W przypadku biografii takiej jak biografia Herberta do tej uniwersalnej prawidłowości dochodzą jeszcze czynniki szczególne: dwadzieścia lat, jakie dzieli nas od śmierci tego poety, to jednak dystans czasowy wciąż niewielki, dyskusja o życiu autora Pana Cogito - chcemy tego czy nie - zahacza o tematy będące przedmiotem aktualnych dziś dyskusji (i kłótni) politycznych. By nie być gołosłownym: radykalny krytycyzm, z jakim Herbert odnosił się do polskiej rzeczywistości lat 9o., słyszymy dziś nieuchronnie jako głos w bynajmniej niezamkniętym sporze o ocenę pierwszej dekady istnienia III RP, sporze przecież tyleż uwikłanym w bieżące interesy polityczne, co ideowo fundamentalnym, przy tym mającym zdecydowanie więcej niż dwie strony. Innymi słowy: jest biografia Herberta częścią nieodległej a wciąż dyskutowanej przeszłości, łączą ją rozmaite nitki z naszą teraźniejszością, stanowi zatem temat niewystudzony dystansem lat i zdarzeń.

A przy tym wszystkim, dodajmy, by domknąć już ów katalog uzasadnień dla „ważności” omawianej książki, dwutomowy Herbert to przejaw wielokrotnie już dostrzeganej i znaczącej tendencji kulturowej, jaką jest koniunktura na „duże” biografie pisarzy. Herbert. Niepokój i Herbert. Pan Cogito stanowią kolejny element w sekwencji takich publikacji jak biografia Iwaszkiewicza, napisana przez Radosława Romaniuka (tom 1 - 2012, tom 2 - 2017), biografia Gajcego, którą skomponował Stanisław Bereś (2016), biografia Gombrowicza pióra Klementyny Suchanow (2017). I, oczywiście, biografia Miłosza, którą sześć lat temu opublikował sam Andrzej Franaszek.

Mając na względzie wszystkie wskazane wyżej okoliczności, postaram się w tym szkicu określić możliwie sumiennie i wyczerpująco moją reakcję na książkę, nawiązując w pewnej mierze do ocen i stanowisk formułowanych już przez recenzentów, którzy głos zabierali wcześniej. Porządek wywodu będzie tu następujący: najpierw spróbuję przyjrzeć się strategiom pisarskim Andrzeja Franaszka (bio-grafia jest wszak pisarstwem), następnie zapytam o całościowy obraz bohatera, jaki się z tego pisarskiego przedsięwzięcia wyłania oraz podzielę się szeregiem uwag szczegółowych, formułowanych z pozycji kogoś, kto sam zajmował się, dość intensywnie, twórczością Herberta. Na koniec zaś powiem kilka słów o perspektywach, jakie omawiana książka otwiera. 


\section{Jak jest zrobiona biografia Herberta?}

W jednym ze swych wierszy najpóźniejszych Zbigniew Herbert pisał o własnym, domykającym się już życiu jako o całości niespójnej, źle zorganizowanej, niezbornej, dalekiej od klasycznego ideału kompozycji:

życie moje

powinno zatoczyć koło

zamknąć się jak dobrze skomponowana sonata

a teraz widzę dokładnie

na moment przed kodą

porwane akordy

źle zestawione kolory i słowa

jazgot dysonanse

języki chaosu ${ }^{6}$

Takie widzenie, takie odczuwanie własnego życia przez poetę w pewnej mierze kontrastuje z formą, w jakiej jego biografię zamknął Andrzej Franaszek. Książka Herbert jest bowiem pisarskim, narracyjnym konstruktem, pomyślanym i wykonanym ze znaczną precyzją. Zwłaszcza oglądana z dystansu, po skończonej już lekturze, percypowana jako całość, ujawnia wyraźnie swą wewnętrzną łączliwość, swoje spójnościowe mechanizmy. W przeciwieństwie do „życia Herberta” (podkreślam: tak jak zostało ono w cytowanym wierszu wyobrażone!), książka o „życiu”, chociażby, „zatacza koło”.

Dzieło Franaszka zaczyna się krótkim opisem pokoju Zbigniewa Herberta w jego warszawskim mieszkaniu na Mokotowie - tym ostatnim już mieszkaniu, z którego wieczorem 27 lipca 1998 roku poetę zabrała do szpitala karetka pogotowia; kilka godzin później Herbert zmarł. Opis pokoju skupia się na emblematach i instrumentach twórczej pracy pisarza - biurku, bibliotece. Zaczyna się więc ta książka od przywołania miejsca opuszczonego, pozbawionego obecności człowieka, który w miejscu tym żył i pracował. Franaszek wybiera apofatyczną strategię reprezentacji - eksponuje brak, który, pośrednio, świadczy o utraconej obecności. Już jednak w owym krótkim module wstępnym, poprzedzającym właściwą „akcję”, biograf wykracza poza czysto negatywną zasadę przedstawienia, gdyż przedmioty zgromadzone w pokoju wykazują się mocą (lub, jak kto woli, przedmiotom zgromadzonym w pokoju

6 Z. Herbert Brewiarz w: tegoż Wiersze zebrane, oprac. edyt. R. Krynicki, Wydawnictwo a5, Kraków 2008, s. 640. 
przypisana zostaje, na prawach narratorskiej licencji, moc) wywoływania minionej realności. Taki właśnie mechanizm włącza się już w pierwszym zdaniu biografii:

Na środku pracowni Zbigniewa Herberta stoi biurko, a właściwie ustawiony na koziołkach jasnobrązowy blat, podarunek od niemieckiej reżyserki filmów dokumentalnych, który przyjechał tu z Berlina pojemnym volkswagenem na początku lat siedemdziesiątych wraz z kartonem pełnym książek. [tom 1, s. 11]

I tak wokół opuszczonego mebla zaczyna się zawiązywać opowieść o jakimś fragmencie skończonego już życia, minionego już czasu. Podobna perspektywa rządzi też modułem finalnym książki Andrzeja Franaszka. Znów, tak jak w module wstępnym, w centrum uwagi znajdują się przedmioty należące niegdyś do poety, tyle że przechowywane nie wjego pokoju, lecz w archiwum, zdeponowanym w Bibliotece Narodowej, w teczkach z notatnikami, rękopisami, maszynopisami. Narrator-biograf wylicza i plastycznie opisuje sekwencję drobiazgów (znaczki na list, bilety, niezażyte lekarstwa, podkładki do piwa, wycinki z gazet), przydając im wszystkim wspólne określenie: „wióry życia”.

Klamrowa kompozycja, można zatem powiedzieć, nadaje książce zasadniczą, strukturalną spoistość, silną ramę, zarazem ustanawiając pewien szczególny rytm myślenia biograficznego. Opowieść wychodzi od opisu pozostawionych przez poetę przedmiotów, który "samorzutnie” przeradza się w „rekonstrukcję poety” (strony 11-15 tomu 1); „rekonstrukcja poety” rozgrywa się w całej swej intensywności na stronach 16-826 tomu 1 oraz 9-828 tomu 2; na koniec od „rekonstrukcji poety” wracamy do pozostawionych przez poetę przedmiotów i ich opisu (strony 829-830 tomu 2). Jeszcze inaczej: rytm tej książki to rytm przechodzenia od residuów do „próby całości” i od „próby całości” do residuów.

W pewnym uproszczeniu można przyjąć, że przedzielająca dwa opisy przedmiotów próba odtworzenia porządku „życia” ma przebieg linearny i chronologiczny. Owszem, nieodzowne stają się tu, jak w każdej zapewne biografii, nawroty, repryzy, powtórzenia, często sygnalizowane na poziomie metatekstowych wstawek („o tym przyjdzie nam jeszcze powiedzieć”, ,jak już wspomniano"), ale zasadniczo linia opowieści wiedzie wciąż naprzód: zaczynając od źródeł i korzeni (od historycznego portretu rodzinnego miasta poety, Lwowa, i od drzewa genologicznego), przez najwcześniejsze dzieciństwo, szkołę, okres okupacyjny, pierwsze lata powojenne... aż do akcentu 
domykającego w postaci ceremonii pogrzebowej na warszawskich Powązkach. Życie poety zyskuje w ramach swej narracyjnej reprezentacji wyrazistą strukturę, czemu (między innymi) służy kilka chwytów, kilka sposobów zestawiania faktów, takich jak (to moje określenia, autor się nimi nie posługuje) prefiguracja, paralela, opozycja.

Co się tyczy pierwszego z pojęć wymienionych, Andrzej Franaszek lubi widzieć rozmaite zdarzenia z życia poety jako - rozpoznawalne z perspektywy ex post - zapowiedzi wydarzeń późniejszych. I tak, „ucieczki”, czyli samowolne oddalanie się z domu cztero- i pięcioletniego Zbysia (zachowania dla niego typowe, wedle cytowanej w książce relacji siostry) stają się w tej perspektywie zapowiedzią późniejszych zachowań dorosłego już poety, który, jak powiada biograf, „odchodzi, wyrusza na samotne wędrówki, każe na siebie czekać, czasem zaś gubi się gdzieś, poszukiwany przez żonę, przyjaciół, organizatorów spotkań literackich" [tom 1, s. 87].W intensywnie przygnębiającym doświadczeniu, jakim dla kilkulatka miało być zobaczenie (pierwszy raz w życiu) martwego zwierzęcia (że do zdarzenia takiego doszło i tak zostało przeżyte, utrzymywał sam Herbert w swoich autobiograficznych narracjach), zaznacza się już - powiada Franaszek - czułość wobec tego, co „skazane na przegraną, cierpiące" [tom 1, s. 89], będąca później ważnym komponentem Herbertowego światoodczucia (ujawnianego np. w esejach poświęconych ludom wyniszczonym przez silniejszych najeźdźców).Za każdym razem działanie metabiograficznego tropu jest podobne: „późniejsze” jawi się w świetle „wcześniejszego” jako wzmacniające powtórzenie, „wcześniejsze” zaś w świetle „późniejszego" jako swoisty wzór czy archetyp.

Paralela to chwyt stosowany najczęściej dla ukazania Herberta w siatce relacji rodzinnych, synowsko-rodzicielskich. Paralela zostaje ustanowiona między ojcem a synem. Bolesław Herbert, rocznik 1892, żołnierz I Brygady w latach 1914-1915 oraz Wojska Polskiego z lat 1918-1920, rozmijał się, jak czytamy, z bezpośrednią walką frontową („słabego zdrowia, choruje na czerwonkę i zapalenie płuc, większość czasu spędza w austriackich szpitalach, by ostatecznie zostać uznanym za niezdolnego do służby wojskowej”; „kiepskie zdrowie trzyma go z dala od pól bitewnych wojny polsko-bolszewickiej", tom 1, s. 47). Podobnie, zauważa narrator-biograf, potoczy się los syna (rocznik 1924), zbyt młodego, by zostać objętym mobilizacją w sierpniu 1939, później zaś nieangażującego się w zbrojną walkę podziemną (choć, dodajmy, mającego doświadczenie konspiracyjno-podziemne, był przecież Herbert uczniem tajnych kompletów i studentem podziemnej polonistyki lwowskiej, o czym, rzecz jasna, w biografii także przeczytamy). Paralela z matką, także 
przez Andrzeja Franaszka budowana, to z kolei kwestia łączącego Marię Herbertową i jej syna doświadczenia choroby dwubiegunowej, objawiającej się mentalną oscylacją między okresami euforii i depresji (tom 2, s. 210-211).

Relację syna i ojca określa również zasada opozycji; można nawet powiedzieć, że Bolesław Herbert jest w narracji Andrzeja Franaszka figurą obrotową: ukazywany, jak wyżej wspomniano, w paraleli z synem, gdzie indziej staje się jego przeciwieństwem, mianowicie jako mężczyzna silny, osobowość stabilna, „człowiek odnoszący zawodowe sukcesy i cieszący się statusem rzeczywistej głowy rodziny”. Jak dopowiada zdanie dalej biograf: „Zdobyć wszystkie te elementy męskiego wizerunku przyjdzie Zbigniewowi o wiele trudniej" (tom 1, s. 49).

Zapewne, wszystkie te konstrukcyjne właściwości napisanej przez Andrzeja Franaszka biografii, wszystkie jej licencje, tropy i retoryczne modusy są dyskusyjne, tzn. - mogą budzić różne reakcje, spotykać się z rozmaitymi ocenami, zależnie od gustu, wrażliwości, czy nawet opcji filozoficznych czytelnika, od tego, w co skłonny jest on wierzyć w sprawach relacji tekstu i rzeczywistości, w co zaś woli powątpiewać. Nieuchronnie rodzi się bowiem pytanie: na ile tego rodzaju strategie prowadzą do odsłonięcia, na ile zaś do przesłonięcia rzeczywistości. Zwłaszcza że cel tej biografii zdefiniowany został w kategoriach nie retoryczno-pragmatycznych (stworzyć opowieść pasjonującą i sugestywną, bo przecież mimesis i tak jest niemożliwa), a esencjonalistycznych, zakładających docieranie do (owszem, w pełni niedostępnej, lecz realnej jako horyzont dążenia) prawdy o człowieku (pośrednio zaś - o świecie w którym człowiek ów żył, o ludziach, którzy istnieli z nim i wokół niego). Taką postawę zapowiada już nadrzędne motto całej książki, zaczerpnięte z poezji Herberta, a zarazem odsyłające nas do założeń klasycznej hermeneutyki: „żebym rozumiał innych ludzi inne języki inne cierpienia”. Pytanie zatem: na ile metabiograficzne tropy, takie jak, właśnie, prefiguracja, paralela, opozycja, są tu chwytami tylko kompozycyjnymi (pozwalającymi ułożyć opowieść o życiu), na ile zaś narzędziami rozumienia. Czy, chociażby, ,stabilny” ojciec-urzędnik i „rozbity” syn-poeta nie jest pułapką, zastawioną po trosze przez autobiograficzne narracje samego Herberta, po trosze przez klisze kultury? I czy np. nie został w książce jakoś umniejszony (bo przeoczony nie został na pewno, przeczytamy i o tym!) wizerunek ojca-partnera dla syna w literackich pasjach i dyskusjach? Żeby było jasne: Andrzej Franaszek nie jest biografem wierzącym bezkrytycznie w moc swego biograficznego dyskursu, dokładnie przeciwnie, wielokrotnie, rzekłbym, inscenizuje przed oczami czytelnika swój autosceptycyzm. By nie szukać daleko - wprowadzając prefiguracyjną 
interpretację dziecięcej ucieczki dodaje natychmiast: „Nie można nadawać anegdotom z życia kilkulatka przesadnego znaczenia”, i dalej „może kreślimy obraz bardzo grubą kreską" (tom 1, s. 87) - ostatecznie jednak, mimo zgłaszanych wątpliwości, kuszący go trop podejmuje.

W ogóle właściwością biograficznego dyskursu Andrzeja Franaszka nie jest w tej książce dążenie do przezroczystości, skrywania instancji samego biografa pod maską narratora „cichego", dyskretnego operatora opowieści. Obecność narratora-biografa jest silnie wyczuwalna - nie przede wszystkim nawet w metatekstowych zwrotach w rodzaju "my jednak wolimy powiedzieć" (projektujących rodzaj wspólnoty między autorem i czytelnikiem biografii), ale właśnie w passusach „literackich”, w których Franaszek rekonstruuje (czy konstruuje?) scenerię, w jakiej rozgrywało się jakieś zdarzenie rzeczywiste lub potencjalne (wiele znajdziemy w biografii imaginacyjnych ćwiczeń w stylu: mógł Herbert być w Starym Teatrze w Krakowie w styczniu 1945 roku i „wśród klaszczącego entuzjastycznie tłumu na widowni” wsłuchiwać się „w głos autora czytanych niedawno Trzech zim”).

Jeszcze raz: rozmaicie można na ten styl bio-pisarstwa reagować, mnie zasadniczo się on podoba, dla mnie ta książka była, poza wszystkim innym, lekturową przyjemnością. Wiadomo, „de gustibus...”. Owszem, gdy czytam taki oto passus o małżeństwie dziadków Zbigniewa od strony ojca:

Trwała la belle époque, zdrowe było pobudzanie apetytu, ustrój zażywnych panów w tużurkach domagał się leczniczej żytniówki, a doświadczony, mający już za sobą jedno małżeństwo Józef oraz jego młoda, zapewne ponętna wybranka zamieszkali w lwowskiej kamienicy, złączeni nie tylko ślubem, ale i namiętnością, której owocem byli dwaj szybko zrodzeni synowie. Najbliższe lata upłyną im jednak pod znakiem opowieści o Hiobie: paroletnie dzieci umierają bowiem jednocześnie na dyfteryt, będący wtedy jedną z najgroźniejszych chorób. Trudno opisać uczucia, jakie musiały towarzyszyć tej rodzinnej tragedii. Jedną z jej konsekwencji mogła być żarliwa religijność, którą przez resztę życia będzie przejawiać Maria... [tom 1, s. 44]

- to zastanawiam się, na ile figuratywno-kulturowy w swej naturze język odsłania, na ile zaś przesłania... Myślę też sobie, że do takiej podejrzliwości wcale nie musi skłaniać lekcja (nielubianej przez Herberta, o tym też u Franaszka przeczytamy) dekonstrukcji (na czele z de Manem i jego konceptem "De-facement"), ale lektura starej książki z czasów lwowskiej belle époque 
właśnie, w której to książce mowa jest o pisaniu biograficznym i autobiograficznym jako o uleganiu „pierwiastkowi konstrukcyjnemu” i kulturowym schematom, odgradzającym od „pałubicznej rzeczywistości” (zresztą aż kusi by do cytowanego wyżej passusu zacząć dopisywać: „idąc ulicą, mógł Józef minąć się na niej z młodziutkim Karolem Irzykowskim, który... etc. etc."). Ale ta konfuzja, jakiej doznaję, po prawdzie, w niczym mi nie przeszkadza. Po prostu,jako czytelnik tej biografii czuję się usytuowany między pustym pokojem zmarłego poety i resztkami-kawałkami jego domkniętego już życia, wewnątrz „próby rekonstrukcji”, z niemożnością definitywnego określenia, ile „bios” jest w „grafii”, a ile „grafii” w „bios”..., co być może jest szczegółowym wariantem ogólnego położenia, uniwersalnej kondycji czytelnika literatury - wszelkiej.

Teoria teorią, dyskurs metabiograficzny dyskursem-metabiograficznym, wszystko to ważne, ale przecie nie najważniejsze. Ostatecznie musi się pojawić pytanie o to, co jest stawką tej całej autobiograficznej (narracyjnej, retorycznej, językowej) gry, to jest o obraz człowieka, jaki się wyłania z tego pisania. Zwłaszcza że tak ową stawkę definiuje sam Andrzej Franaszek, ustanawiając następującą puentę swojej książki: „I przynajmniej zbliżyć się do prawdy. Po cóż innego pisać biografię?” (tom 2, s. 832). Jaki zatem „przybliżony wizerunek prawdziwy" wyłania się dwutomowego Herberta?

\section{Jaki Herbert?}

Oczywiście - nie jest to Herbert wyidealizowany, pomnikowy. Nie jest zgodnie z taką oto maksymą, wynotowaną przez biografa:

Czasem musiałem pisać o kwestiach naprawdę trudnych, mogłem się przy tym nieco pocieszać zaleceniem, którym Herbert opatrzył pracę innego biografa: „Niech Pan nie zrobi z niego gipsowego świętego, takiego - wie pan w niebieskim kolorze"7. Tego z pewnością nie zrobiłem. [tom 2, s. 832]

Z pewnością nie zrobił. Czytamy zatem o Herbercie ulegającym swoistej obsesji konfabulacyjnej, podbudowanej kompleksami osobistymi (i,jak twierdzi biograf, także presją polskiej kultury, zorientowanej na gloryfikację walki zbrojnej), obsesji, która przejawiała się tworzeniem - i to w wypowiedziach

7 Taką radę miał Herbert przekazać Jackowi Moskwie, piszącemu o postaci Antoniego Józefa Marylskiego. 
zarówno prywatnych, jak i publicznych - całej palety wariantów własnej wojennej biografii. Różniły się te warianty (skrupulatnie przez Franaszka odnotowywane) stopniem „podkolorowania" $i$,heroizacji”, czasem przybierały formę bardziej skromnościową, czasem ocierały się o całkowite nieprawdopodobieństwo, zawsze jednak ich motywem centralnym była przynależność do Armii Krajowej i wynikająca z niej aktywność konspiracyjno-żołnierska, której przecież nie potwierdzają żadne źródła czy choćby przesłanki, a którą co najmniej podają w wątpliwość różne biograficzne okoliczności (także przez Andrzeja Franaszka wskazywane). Czytamy o chorobie dwubiegunowej, będącej źródłem (czy jednym ze źródeł) psychologicznej, emocjonalnej niestabilności Zbigniewa Herberta, która w swych najostrzejszych przejawach prowadziła do nieuzasadnionych, personalnych, krzywdzących ataków na ludzi poecie życzliwych (i wcale nie mam tu na myśli sposobu wyrażania ocen politycznych w latach 9o. czy nawet konfliktu z Czesławem Miłoszem, lecz np. zachowania wobec Vincenta Giroud czy Pietro Marchesaniego; tego ostatniego zresztą, jak się z biografii dowiemy, poeta, będąc już w innym nastroju czy dyspozycji psychofizycznej, gorąco przepraszał za niesprawiedliwe potraktowanie). Czytamy o, splatającej się z problemami psychologicznymi, chorobie alkoholowej. Czytamy o kwestii kłopotliwych podobieństw, łączących niektóre passusy pewnego eseju Herberta z passusami książki francuskiego mediewisty-amatora (do tej kwestii jeszcze powrócę). Czytamy wreszcie o licznych romansach i związkach z kobietami, w których poeta zachowywał się nieraz egoistycznie, narcystycznie, po prostu nie zawsze i nie do końca odpowiedzialnie i uczciwie.

Oprócz takich tematów pojawiają się też kwestie mniejszego kalibru, dające się zaliczyć do rzędu słabostek, kompleksów, poczynań małostkowych - przykładowo, w obrazie Herberta, wyłaniającym się z tej biografii wyraźnie zaznacza się uraza związana z nieotrzymaniem literackiej Nagrody Nobla (aż chciałoby się powiedzieć: tak jakby mało było wielkich pisarzy, których ona ominęła!). Uraza, dodajmy, przybierająca na sile po werdykcie z roku 1996, przyznającym to wyróżnienie Wisławie Szymborskiej (jak pokazuje Franaszek, cytując, faktycznie zaskakujący, telegram Herberta do Różewicza, zob. tom 2, s. 671).

Nasycenie tej biografii obrazami Herberta cierpiącego, ale i raniącego innych ludzi, zmagającego się z chorobami ciała i duszy, doświadczającego rozmaitych słabości czy po prostu przychwyconego w pozach „niepomnikowych", zmuszonego do (z pewnością przykrych dla niego samego) kompromisów i zachowań z gatunku mimikry (chociażby udział w trójmiejskim oddziale 
Związku Literatów Polskich w latach 1949-1951) jest znaczne, na co zwracali uwagę liczni recenzenci i komentatorzy. Oto dwa cytaty. Najpierw - Ryszard Koziołek, recenzujący książkę Andrzeja Franaszka na łamach „Tygodnika Powszechnego":

Nic na to nie poradzi autor, że czytelnikowi najprawdopodobniej zostanie w pamięci dominujący obraz Herberta jako egotystycznego i egoistycznego kabotyna, zrozpaczonego i zgryźliwego błazna grzęznącego na przemian lub równocześnie w alkoholizmie, erotomanii i depresji, rujnującego związki i przyjaźnie przez swój radykalizm moralny i obsesje polityczne. Tak, czytamy także, że był czarujący, hojny i dowcipny; miał swoje jasne dni, ale nie widzimy ich tak jaskrawo jak scen gniewu, krzywdy i upadku. W niemożliwy do wyjaśnienia sposób przydarzyło mu się być genialnym poetą. ${ }^{8}$

I, dla zestawienia, Andrzej Horubała, ze swoją recenzją, zamieszczoną na internetowym blogu:

Późny Herbert z obrazu, jaki odmalował nam Franaszek, to bowiem schorowany pijaczek, mitoman, na poły wariat, kłamczuszek i nerwus, a nie osamotniony buntownik, którego orężem jest słowo.9

Że obaj recenzenci mówią coś dokładnie przeciwnego, to oczywiste, podobnie jak fakt, że w ogóle cytowane recenzje napisane są zupełnie inaczej, wyrażają całkiem odmienne poglądy i po prostu pochodzą z planet zgoła odmiennych, oddalonych. Ryszard Koziołek przekonuje, że „czarny”, przygnębiający obraz Herberta wyłania się z książki Franaszka wbrew autorskiej intencji, wbrew staraniom biografa-narratora, który usiłuje skupiać uwagę czytelnika na „jasnych" stronach i barwach wizerunku swego bohatera, te jednak, owszem, istnieją, lecz są po prostu, mniej wyraziste, percepcyjnie słabsze. Andrzej Horubała twierdzi zaś, że „czarny obraz” został przez Franaszka odmalowany świadomie, że, innymi słowy, retoryczne i kompozycyjne zabiegi biografa-narratora na osiągnięcie takiego właśnie, nie innego, rezultatu zostały obliczone. A jednak - przy całej oczywistej nieprzystawalności tych dwóch recenzji - zaskakujące może być to jedno elementarne współbrzmienie: obaj

8 R. Koziołek Herbert i jego Pan, "Tygodnik Powszechny” $2018 \mathrm{nr} 33$.

9 A. Horubała Herbert rozwłóczony. Zadanie wykonane, horubala.rewolta.pl (8.01.2019). 
recenzenci stwierdzają, że książka Andrzeja Franaszka pozostawia czytelnika z takim obrazem czy odbiorem autora Pana Cogito, którego dominantą jest ułomność głównego bohatera.

Ilu czytelników - przepraszam za głoszenie banału - tyle możliwych odbiorów, to stara prawda. I bardzo często jest tak - znają to doświadczenie chyba wszyscy rozmawiający o książkach ze swoimi przyjaciółmi, bliskimi, znajomymi, studentami w trakcie zajęć akademickich etc. - że wymieniając się czytelniczymi odbiorami, aż dziwimy się ich odmienności. Czytamy to samo, a tak różnie (co właściwie, znów wypadnie mi przeprosić za prawienie banałów, jest faktem krzepiącym!). Nie inaczej w tym przypadku. Śpieszę z wypowiedzią spersonalizowaną - ja zupełnie nie odnajduję się w tych scenariuszach lektury, jakie nakreślone zostały w przywołanych wyżej $\operatorname{cytatach}^{10}$. Kompletnie nie daję się przekonać do tezy, że tworzenie ciemnego obrazu miałoby być intencją i strategią autora (w tym więc miejscu dystansuję się od odbioru Andrzeja Horubały), ale - przede wszystkim - kompletnie nie mam poczucia, że książka, obojętnie nolens czy volens, uprzywilejowuje wizerunek negatywny swego protagonisty. Naprawdę szczerze wnikam w mój czytelniczy odbiór i stwierdzam, że nic takiego się nie wydarza we mnie, czytelniku. Znajduję dwa wytłumaczenia dla takiego przebiegu recepcji, zacznę od wytłumaczenia mniej ważnego.

Otóż - warto to przypomnieć - praktycznie wszystkie składowe „ciemnego obrazu" obecne w biografii Herberta były bardzo dobrze znane od lat co najmniej kilkunastu i to znane niewtajemniczonym z kręgu „środowiska”,lecz, po prostu, czytelnikom zaciekawionym tym, co o Herbercie można przeczytać. Dokładnie wszystkie"1. Sprawa mityzacji i konfabulacji w kwestii Armii Krajowej, sprawa choroby dwubiegunowej, sprawa alkoholizmu, oskarżenie o wtórność w przypadku jednego z esejów, zawikłania życia erotycznego... Kwestie te były poruszane ( $\mathrm{z}$ bardzo różnych punktów widzenia, w rozmaitych stylistykach i intencjach, z nierówną fortunnością) w wielu publicznych wystąpieniach, m.in. w wymienianych już przeze mnie książkach Siedleckiej, Żebrowskiego, ale też w wywiadach udzielanych przez rodzinę, w tym żonę

10 W scenariuszach tych nie mieści się też odbiór Łukasza Garbala, skoro stwierdza on, że po lekturze książki Franaszka Herbert jest dlań poetą, którego „nie mniej teraz lubię i podziwiam, ale którego bardziej teraz chyba rozumiem; i żałuję” (zob. Ł. Garbal Mozaika Pana Cogito, "Dekada Literacka" $2018 \mathrm{nr}$ 2/3.) szym, który o „trudnych tematach” z biografii Herberta pisze) jest wyraźnie i explicite obecna. 
i siostrę. A przecież w grę wchodzi jeszcze poniekąd autodemaskacyjna korespondencja prywatna samego Herberta, stale i konsekwentnie publikowana ${ }^{\mathbf{1 2}}$, gdzie - zdarza się i tak - słyszymy głos poety samego siebie krytykującego za rozmaite czyny bądź zaniechania. Owszem, biografia Franaszka dopowiada pewną ilość nieznanych wcześniej szczegółów (faktycznie: najwięcej w zakresie życia osobistego, erotycznego), jest to jednak raczej wypełnienie istniejącego już wzorca niż otwieranie nowych pól. Mówiąc krótko, zupełnie nie postrzegam tej biografii jako dzieła „zrzucającego z pomnika” czy „odbrązawiającego", a z takimi określeniami zdarzało mi się spotykać (także w rozmowach prywatnych) - o jakim tu mówimy odbrązowieniu, skoro wszystkie tzw. „trudne tematy” tej biografii zostały już wcześniej co najmniej zasygnalizowane, o ile nie wręcz wyeksploatowane? Nawet postawa Franaszka-biografa wobec autobiograficznych praktyk Herberta nie jest konsekwentnie demaskatorska. Owszem, badacz jest krytyczny - na szczęście, to wszak naczelny obowiązek każdego biografa! - wobec tego, co autor mówił sam o sobie, jak np. wówczas, gdy falsyfikuje opowieści Herberta o byciu studentem uczelni artystycznych (tom 1, s. 230-232). Ale przecież, odnotujmy, biograf niejednokrotnie też ulega czarowi tych Herbertowych autointerpretacji (można tu nawet mówić o pewnej niekonsekwencji), przyjmuje je za dobrą monetę, zawiesza podejrzliwość, chce budować na nich własną opowieść. Tak np. obraz matki jako osobowości mniej niż ojciec i babka wyrazistej, będącej „raczej dopełnieniem, lepiszczem domowego świata", pojawiający się na stronie 67 tomu 1 ewidentnie jest wywiedziony z passusu z listu Herberta do Miłosza, cytowanego stronę wcześniej.

Taka jest więc pierwsza przyczyna, dla której, jak sądzę, wszystkie te, wspominane wyżej, ciemne rysy Herbertowego wizerunku nie jawią mi się jako tak intensywne, że aż zyskujące rangę dominant. Ale jest i powód, drugi, jak napisałem, ważniejszy. Otóż sądzę, że jasne czy chwalebne komponenty tegoż wizerunku, który się z książki Franaszka wyłania, nie są wcale mniej wyraziste, zmarginalizowane - raz, dlatego że nie usiłuje ich marginalizować biograf-narrator (przeciwnie, podkreśla je - tutaj zgadzam się z sądami Ryszarda Koziołka), dwa, że są one, po prostu, bardzo silne i, zwyczajnie, nie dają się łatwo przesłonić, zagłuszyć.

Autor książki odnosi się do swego bohatera z szacunkiem i sympatią. Gdy przychodzi mu relacjonować wypowiedzi Herberta, z którymi jawnie

12 Por. jedną z najnowszych publikacji w tym zakresie: Korespondencja Zbigniewa Herberta i Krystyny Podgóreckiej z lat 1958-1998, oprac. A. Romaniuk, "Dekada Literacka” 2018 nr 2/3. 
i radykalnie się nie zgadza - owszem, poddaje je krytyce, zwykle jednak umiarkowanej, połączonej z próbą uchwycenia takich składowych komentowanego osądu, które, w opinii biografa-narratora, mogą być uznane za trafne, przekonujące ${ }^{13}$. Przede wszystkim jednak bardzo liczne są w tej książce passusy nie polemiczne w ogóle, lecz gloryfikujące. Czytamy zatem o Herbercie, który w roku 1951 decyduje się wystąpić ze Związku Literatów Polskich, ponieważ nie chce dłużej znosić nawet tego minimalnego poziomu kompromisu, jakiego wymagało samo uczestniczenie w jego trójmiejskim oddziale. Czytamy o Herbercie, który w grudniu roku 1971, podczas wieczoru poetyckiego na Zamku Wawelskim, upomina się, w pierwszą rocznicę zdarzenia, o pamięć ofiar masakry na Wybrzeżu. Czytamy o Herbercie, którego Służba Bezpieczeństwa charakteryzuje w swoich dokumentach z lat 70. jako ideowego przeciwnika władzy, niebezpiecznego, bo wywierającego niepożądany wpływ na młodzież. Czytamy o Herbercie - to ważny trop tej biografii, mam wrażenie, że trochę za mało dostrzegany - jako o człowieku po prostu życzliwym innym ludziom, gotowym do niesienia bezinteresownej a konkretnej pomocy; dość przywołać passusy o relacji z młodym Ryszardem Krynickim w latach 70. i 8o. (w których Herbert jawi się jako spolegliwy opiekun, w jakiejś mierze doradca, gdy zachodzi potrzeba, niezawodny przyjaciel), dość wspomnieć te karty, na których Franaszek pisze o zaangażowaniu Herberta, także finansowym po prostu, w organizację pomocy dla ludzi dotkniętych represjami w stanie wojennym. Czytamy o Herbercie z życzliwością patronującym poczynaniom Janusza Szubera. Czytamy o Herbercie, który w trakcie podróży do Izraela w roku 1991 (jechał, by odebrać prestiżową nagrodę literacką) planuje wystąpienie w obronie praw ludności kurdyjskiej na Bliskim Wchodzie - czytamy też następujący komentarz Franaszka w tej sprawie:

Ilu europejskich poetów, lecąc do Izraela po odbiór nagrody literackiej, zamiast planować swoje wystąpienie, chciałoby przygotowywać

13 Dobrze to widać na przykładzie tych partii, które poświęcone są trudnym relacjom Herberta i Miłosza, a w których Andrzej Franaszek wyraźnie zachowuje bezstronność, szuka stanowiska wyważonego, stara się rozumieć racje i reakcje bohaterów obu swych książek biograficznych (zob. tom 1 rozdz. Kamień na sercu, tom 2, s. 681-685). Najmniej może "hermeneutyczna” (w znaczeniu: szukająca możliwości zrozumienia), najmniej otwarta na racje bohatera biograficznej opowieści jest narracja dotycząca Herbertowskiej krytyki polskiej rzeczywistości politycznej w latach 90., zdecydowanie nieprzekonującej biografa-narratora (i bodaj rzeczywiście potraktowanej ze zbyt nikłym nakładem empatii). 
spotkanie w obronie mordowanych w jakimś zakątku globu nieznanych sobie ludzi? (tom 2, s. 648-649)

W ogóle słów uznania dla głównego bohatera - nie tylko dla jego twórczości literackiej, lecz właśnie dla jego postawy, ujawniającej się w kontaktach z ludźmi - jest w tej książce wiele i są to słowa mocne: heroizm, odwaga, bezkompromisowość, męstwo, szlachetność, przyjacielskość... Naprawdę więc jest to opowieść - per saldo, co do dominanty - o „kabotynie”? Nie w moim odbiorze. I jeszcze jedno: przewijającym się motywem Franaszkowej biografii jest opisywanie twórczości Herberta jako aktu heroicznego, właśnie dlatego, że polegającego na przezwyciężaniu psychofizycznej słabości, związanej z wydłużającą się, szczególnie w ostatniej dekadzie życia poety, listą chorób i dolegliwości. Ukazywane przez Andrzeja Franaszka obrazy ciężko chorego Zbigniewa Herberta, który nie może podnieść się z łóżka, jest podpięty pod rurkę z tlenem, nadal jednak tworzy poezję, są obrazami ludzkiego heroizmu. I przypuszczam - mogą jako takie być odbierane w gruncie niezależnie od tego, czy Herbertową poezję ceni się szczególnie wysoko jako samoistną wartość estetyczną (a takie jest wartościowanie Andrzeja Franaszka, które podzielam) czy, przeciwnie, uważa się ją za zjawisko mniej czy bardziej przecenione (bo przecież i takie głosy były już w krytyce literackiej wypowiadane, są głoszone dziś i w przyszłości zapewne ich nie zabraknie). A skoro mowa o przedstawieniach choroby Herberta w opowieści jego biografa, to dodam jeszcze, że wśród ilustracji zamieszczonych w książce (jest ich wiele) wrażenie szczególnie przejmujące wywiera na mnie jedno zdjęcie: to z okolic roku 1998, ukazujące Herberta jako człowieka równocześnie cierpiącego i pracującego.

Coraz bardziej zagłębiam się w swój własny odbiór książki, coraz wyraźniej mówię tu o tym, jak rezonuje ona we mnie, pora zatem określić dokładniej usytuowanie mojej lektury. Książkę czytało mi się bardzo swoiście, inaczej niż pozostałe biografie pisarzy, ukazujące się w latach ostatnich, gdyż w istotnej mierze dotyczy ona materii, którą sam się intensywnie zajmowałem. Archiwum Zbigniewa Herberta dość dobrze znam, po raz pierwszy zetknąłem się z nim, dzięki uprzejmej zgodzie pani Katarzyny Herbert, w roku bodaj 2004, gdy było ono jeszcze zbiorem prywatnym, potem wiele godzin spędziłem w BN-owskiej czytelni zbiorów specjalnych, poznałem też niewielką cząstkę amerykańską, czyli Zbigniew Herbert's Papers w Beinecke. To moje obcowanie wiązało się z pracą doktorską, poświęconą wczesnej twórczości Herberta (spuentowaną książką Otwieranie głosu z roku 2009), przede wszystkim zaś z przygotowywaniem - wraz z zespołem grantowym - monografii Pracownia 
Herberta $^{14}$ (2017), pomyślanej jako próba zrozumienia i opowiedzenia dynamiki procesu tekstotwórczego (już wprawdzie zakończonego, lecz jakoś dostępnego poprzez swe śladowe, czyli słabe, zapośredniczenie, czyli brulion). Książkę Andrzeja Franaszka czytałem zatem jako relację podróżnika, którego drogi przecinały się w pewnej mierze z moimi poszukiwaniami. Rzecz jasna, penetrowaliśmy to samo terytorium $\mathrm{z}$ odmiennym nastawieniem, on był biografem, ja krytykiem genetycznym, ale te profesje jakoś się wzajemnie przenikają. Interesujące było więc dla mnie przyglądanie się koniunkcjom i dysjunkcjom naszych ustaleń - o tym też chciałbym teraz opowiedzieć.

\section{Zgody, zdania odrębne, dopowiedzenia (czyli odrobina pedanterii)}

Zacznę od wskazania spraw czy wątków, które mnie w tej biografii szczególnie zafrapowały. Generalnie - ciekawe były dla mnie cytaty z niepublikowanej korespondencji Herberta, przechowywanej głównie w warszawskim archiwum, ciekawe były też komentarze na lekturze takich listów opierane. Tej części archiwum nie znam - sam zajmowałem się głównie notatkami, brulionami, rękopisami etc. związanymi bardziej bezpośrednio z pracą literacką; gdy więc Andrzej Franaszek opowiada swemu czytelnikowi o brulionach poety, miałem zazwyczaj poczucie déjà vu (i od razu pokusę porównywania relacji biografa z moimi doświadczeniami), gdy jednak cytuje niepublikowane listy (zwłaszcza korespondencję Katarzyny i Zbigniewa Herbertów), chłonę je jako materiał całkiem i dla mnie premierowy.

Ciekawa była dla mnie hipoteza (czy ostatecznie potwierdzona bądź dająca się potwierdzić?) o autorstwie Herberta w odniesieniu do kilku felietonów krytyczno-artystycznych, ogłaszanych pod koniec lat 50. na łamach polonijnych pism w Paryżu i Londynie (zob. tom 2, s. 642-645).

Interesującym wątkiem było też z mojej perspektywy podjęcie tematu, który hasłowo określić by można jako „Herbert a sztuka nowoczesna”, „Herbert a awangarda". Nie jest to z pewnością temat wiodący książki (tak jak i nie jest to jakiś wybitny wątek Herbertowskiej refleksji estetycznej), pojawia się on na zasadzie wzmianek - ale pojawia ciekawie. Najogólniej rzecz ujmując, zachodzi tu pewna dynamika zainteresowan. Herbert około połowy lat 50., zwłaszcza w latach 1956-1957 (a więc przeszło trzydziestoletni, debiutujący 
właśnie jako autor tomików poetyckich) jest zaciekawiony - powiedzmy nieco oksymoronicznie - tradycją awangardy (czyli awangardą historyczną, sprzed wojny, z początków XX wieku) oraz aktualnymi przejawami żywotności projektu awangardowego: czyta z zapałem i zachwytem pisma Strzemińskiego, ogląda II Wystawę Nowoczesnych, interesuje go język plastyczny Marii Jaremy czy Andrzeja Wróblewskiego, spotyka się z Tadeuszem Peiperem (zob. tom 1, s. 596-599). To ciekawe, bo przecież, zwłaszcza w odbiorze potocznym, Herbert zdaje się dość daleki od terytorium awangardy i sztuki eksperymentalno-nowoczesnej (co prawdą jest, właśnie, nie do końca). Choć fakt, że wraz z upływem czasu Herbertowskie zaciekawienie awangardą jakby przygasa, co zresztą biografia Franaszka wychwytuje (por. tom 1, s. 661).

Wreszcie - nie zdawałem sobie faktycznie sprawy (a Franaszek, moim zdaniem, pokazuje to przekonująco), do jakiego stopnia Herbert późny, z przełomu lat 8o. i 9o., zaangażował się intelektualnie, emocjonalnie, nawet w pisarsko, w próbę zrozumienia własnej biografii poprzez wzorzec czy archetyp ofiary (jaką miał być - on sam). Coś mi w tym kierunku zaczynało świtać, gdy Karina Jarzyńska, w ramach kierowanego przeze mnie grantu, pracowała nad szkicem o Roku jagnięcia, czyli ostatecznie nigdy nieskonstruowanej, lecz intensywnie obmyślanej - właśnie, jak to powiedzieć? - próbie duchowej autobiografii, podjętej przez Herberta w roku 1991. Próba ta w dużej mierze właśnie wokół motywu „ofiary” krąży. Szkic Jarzyńskiej można przeczytać w Pracowni Herberta..., teraz jej propozycję odszyfrowania enigmatycznego dzieła-widma (dla poety bardzo ważnego, bo mającego być odpowiedzią na Rokmyśliwego) zestawić można z nieco odmiennym ujęciem zawartym w biografii. Andrzej Franaszek trafnie pokazuje, jak ów „motyw ofiarny” pojawia się także w innych niż Rokjagnięcia, sui generis autobiograficznych wypowiedziach Herberta, sprawę tę sygnalizuje już na wstępie książki, pisząc:

W smudze cienia, w okolicy sześćdziesiątych urodzin, w paryskich szpitalach, w drugiej połowie lat osiemdziesiątych, obolały, chory na ciele i duszy, będzie próbował odkryć wzór swojej biografii, dostrzegając w niej przede wszystkim poświęcenie, los tego, który jest przeznaczony na ofiarę. [tom 1, s. 15]

Ciekawe to zdanie i chyba wskazujące na temat, który można jeszcze dalej przemyśliwać, od siebie dodam tylko: kluczowe jest tu sformułowanie „będzie próbował" i jego tryb niedokonany. Bo tej symbolicznej wykładni własnej biografii nigdy się Herbertowi nie uda złożyć, forma niedoszłego 
Roku jagnięcia (będącego dziś stosem kilkuset kart, zwykle częściowo tylko zapisanych, niesłychanie trudno czytelnych, ułożonych - nie wiadomo do końca wedle jakiej i czyjej logiki - w kilku archiwalnych teczkach) jest tu, rzekłbym, emblematyczna.

Przechodzę z kolei do działu „, autoerraty”, , autosuplementy”, to jest odnotowuję, gdzie ustalenia Andrzeja Franaszka pozwoliły mi rozpoznać lapsusy w moich własnych publikacjach, ewentualnie, gdzie wnoszą one istotne uzupełnienia, dodają poszerzający kontekst. I tak: Franaszek zauważa bardzo faktycznie ciekawy (jako dokument dynamiki kształtowania się osobowości twórczej poety, nie jako samodzielne dokonanie artystyczne) juwenilny i nigdy dotąd niepublikowany wiersz Po boju (powst. w roku 1945) i umiejętnie wkomponowuje go w swoją narrację (zob. tom 1, s. 214) - ten utwór jakoś przeoczyłem, tworząc przed laty dziesięciu swoją opowieść o poetyckich inicjacjach Herberta w książce Otwieranie głosu (choć zbiór juweniliów jak najbardziej wertowałem i opisywałem). Z kolei w Pracowni Herberta (2017) ustalałem, że najwcześniejsze zapiski, w których pojawia się imię Pana Cogito pochodzą z roku 1964; Franaszkowi udało się znaleźć zapis wcześniejszy o dwa lata (tom 2, s. 410). Pisząc w tejże monografii osobny rozdział o pracy Herberta nad nigdy ostatecznie niesfinalizowanym - dramatem Baśń zimowa, przeoczyłem fakt przez Franaszka odnotowany, ten mianowicie, że dramat ów powstawał na zamówienie niemieckiego nadawcy radiowo-telewizyjnego. Co skłania mnie do następującej, ogólniejszej samokrytyki: sądzę, że nie udało się w redagowanej przeze mnie Pracowni Herberta uwypuklić w dostatecznej mierze, by tak rzec, instytucjonalno-socjologicznego kontekstu procesu twórczego, a więc właśnie roli wydawców i wydawnictw jako elementu stymulującego (czy w każdym razie współdeterminującego) przebieg pisarskiej pracy.

Potraktowawszy książkę Andrzeja Franaszka jako książeczkę do rachunku sumienia, mogę z czystszym sercem przejść do innego wyliczenia, formułując listę polemik, wątpliwości, interpretacji alternatywnych, dotyczących zresztą raczej szczegółów, często nawet pojedynczych zdań. Nie chcę przywoływać tu wszystkich sytuacji, w których coś widzę inaczej (grzechy własne też bodaj nie wszystkie wyznałem...), gdyż zrobiłby się z tego jakiś ultrapedantyczny protokół zdań odrębnych, poprzestanę na dwu uwagach przykładowych.

Uwaga pierwsza dotyczy drobiazgu, jak wszakże sądzę, wdzięcznego i ciekawego. Andrzej Franaszek pisze:

Chodasiewicza próbował Herbert zrównoważyć wierszem Do Czesława Mitosza, ale prawdę powiedziawszy, mimo bodaj szczerych intencji osiągnął 
efekt tyleż nieprzekonujący, ile niezamierzenie ironiczny. Sam zresztą rękopis tego utworu, datowany 26 lipca 1991 roku, opatrywał sceptyczną frazą "ale pociekło” (tom 2, s. 766).

Wiersz Do Czesława Miłosza, drukowany w tomie Rovigo, jest - także i w moim odczuciu - wierszem, by tak rzecz ująć, nieprzejrzystym, właściwie nie mam wyrobionego sądu w kwestii zamierzonego „wydźwięku” (ironiczny czy pojednawczy?), nie jestem też pewien, co wiersz ten mówi „sam sobą", niezależnie od intentio auctoris $^{15}$. Jestem wszakże bodaj pewien, że dopisek „ale pociekło" - który swego czasu zwrócił i moją uwagę - ma inne znaczenie. W notatniku znajdującym się w zbiorach Biblioteki Narodowej w Warszawie i opatrzonym archiwalną sygnaturą akc. 17955 t. 150 odnajdujemy całą serię pierwszych, brulionowych inskrypcji następujących wierszy: Do Piotra Vujičića, Obłoki nad Ferrara i właśnie Do Czesława Miłosza (zresztą pierwotnie noszący tytuł Nad zatoką i dedykację „Czesławowi Miłoszowi”). Wszystkie one zapisane zostały tą samą fioletową kredką, podobnym duktem pisma - jakby w jednej sesji pisarskiej - wreszcie pod wszystkimi widnieje ta sama data „26 VII [1991]”. W tej sytuacji, sądzę, metatekstowa wstawka „ale pociekło" (warto dodać: napisana na tej samej stronie, co liryk Do Czesława Miłosza, lecz w znacznym oddaleniu od samego tekstu, natomiast bezpośrednio pod datą 26 VII 91) jest raczej komentarzem do nieoczekiwanej erupcji sił twórczych, nie zaś do jakości osiągniętego rezultatu.

Uwaga druga odnosi się zaś do kwestii kłopotliwej relacji intertekstualnej, wiążącej esej Herberta Kamień z katedry (z tomu Barbarzyńca w ogrodzie) oraz książkę Jeana Gimpela Les bâtisseurs de cathédrales, opublikowaną we Francji w roku 1958. Kwestię tę podniosła w roku 2004 Dorota Bielawska, stwierdzając (i ilustrując to twierdzenie szeregiem porównawczych cytacji), że w Kamieniu $z$ katedry „znaleźć można całe zdania i wyrażenia bezpośrednio zaczerpnięte z książki Gimpela lub nieznacznie sparafrazowane"16. Andrzej Franaszek w swojej biografii przywołuje ustalenia Bielawskiej i przyznaje

15 Wiem natomiast, że wątpliwości, co do intencji Herberta nie miał raczej sam Miłosz - otóż uznał on ten utwór za ewidentnie ironiczny, właściwie widział w nim ciąg dalszy personalnego ataku z Chodasiewicza. Pisał o tym w niepublikowanym tekście wspomnieniowym, powstałym już po śmierci Herberta, będącym (najwyraźniej trudną dla autora Roku myśliwego) próbą podsumowania relacji z dawnym przyjacielem. Tekst ten przygotowywany jest do druku w tomie ZArchiwum, mającym się ukazać w serii Dziełzebranych Czesława Miłosza w roku 2020.

16 D. Bielawska Jak został wyciosany „Kamień z katedry” Zbigniewa Herberta, "Twórczość” 2004 $\mathrm{nr} 2 / 3$, s. 230. 
im (co podkreśla: z przykrością) pełną rację. A nawet przydaje argument dodatkowy, którym jest biblioteka poety, jak się dowiadujemy, faktycznie zawierająca książkę Gimpela w wydaniu z roku 1958. Co do mnie: rozumiem stanowisko biografa, rozumiem, że argumentacja Bielawskiej po prostu go przekonuje. Sam daleki jestem od prób całkowitego zanegowania jej wywodu, mogę się (również z przykrością) zgodzić, że, faktycznie, istotne partie Herbertowego eseju są wtórne wobec eseju francuskiego (odbijają logikę jego wywodu, powielają dość mechanicznie pewne schematy wyrażeniowe czy zbitki pojęć) i zaiste byłoby lepiej, gdyby autor Barbarzyńcy w ogrodzie po prostu ujawnił - jednym chociaż wtrąceniem - istnienie owej tekstowej matrycy. Co stwierdziwszy, sądzę, że, mimo wszystko, mogłoby się tu jeszcze znaleźć miejsce dla nieco bardziej cieniującego komentarza. Andrzej Franaszek poprzestaje na zacytowaniu retorycznego pytania Doroty Bielawskiej: „co można sądzić o oryginalności eseju Herberta, skoro ponad dwie trzecie tekstu Kamienia z katedry (pomijając część wstępną) ma swoje «odpowiedniki» w książce Gimpela?".Ja byłbym skłonny zbudować tu jednak pewną odpowiedź: otóż o tej oryginalności sądzić można to np., że pasożytuje ona na wypisach z Gimpela, jak wówczas, gdy w akapicie niewątpliwie inspirowanym francuskim wzorem, a mówiącym o ciężkiej, anonimowej doli robotników pracujących w średniowiecznych kamieniołomach pojawia się nagle piękna metafora, niemająca, o ile mi wiadomo, „odpowiednika” w książce Francuza: „A przecież bez nich, trudzących się w wilgotnych i ciemnych podziemiach, bez nich, którzy wykuwali negatyw katedry w skale, nie byłoby do pomyślenia to, co stworzone zostało na podziw ludzkich oczu". Fotograficzna metafora jest tu właśnie przejawem oryginalności - fakt, że zaszczepionej na gruncie wtórności. I jeszcze jedno dopowiedzenie: we fragmencie książki Franaszka, poświęconej „sprawie Kamienia z katedry przydałby się jednak - dla pełniejszej orientacji bardziej dociekliwego czytelnika - chociaż krótki bibliograficzny przypis, odsyłający do dyskusji wokół artykułu Doroty Bielawskiej, toczącej się w roku 2004 na łamach „Twórczości” (m.in. z udziałem Brigitte Gautier, starającej się zbijać stawiane Herbertowi zarzuty, ale też ze zgoła inaczej brzmiącym głosem Henryka Markiewicza) ${ }^{17}$.

Pisząc o swoim odbiorze omawianej biografii, chciałbym poruszyć nieco dokładniej jedną jeszcze kwestię.

17 Skoro mowa o bibliografii - nowe i ciekawe omówienie sprawy Kamienia z katedry znaleźć można na internetowym blogu Kompromitacje. Przypadki słabości ludzkich (kompromitacje. blogspot.com; 9.01.2019). 


\section{Jak pisać o pisaniu?}

Proces tekstotwórczy to jeden z zauważalnych tematów tej biografii, nie pierwszoplanowy może, lecz z pewnością mocno eksponowany. Interesuje Franaszka Herbert, który się waha - w trakcie pisania, nie zaś ten tylko, który stoi za dziełem już gotowym, zamkniętym w ostatecznej formule. Ciekawi go zatem Herbert pochylony nad kartką, podejmujący i zmieniający decyzje stylistyczne, kompozycyjne, ideowe. Jak wtedy np., gdy w brulionie małej prozy Matka (ostatecznie włączonej do tomu Pan Cogito) początkowo wprawia w ruch frazę „upadłem jej z kolan jak kłębek włóczki”, by, koniec końców, nadać temu zdaniu kształt: „Upadł z jej kolan jak kłębek włóczki”, dokonując tym samym wyraźnego gestu zatarcia ,ja”, likwidacji, czy, ostrożniej mówiąc, osłabienia autobiograficznego wymiaru tekstu (tom 2, s. 79). Kiedy indziej Franaszek ukazuje czytelnikowi działanie mechanizmu substytucji: wiersz pisany po śmierci matki, rozpoczynający się od słów „moja mama / nigdy nie pięła się w górę" zostaje przerwany, poniechany, w jego miejsce pojawia się utwór inny, zatytułowany Tren, który już będzie ukończony i opublikowany. Biograf-badacz procesu unaocznia też ciekawie zjawisko osmozy, zachodzącej między językiem epistolarnym i poetyckim, jak wówczas np., gdy zalążki wiersza Tarnina zdają się już wykształcać w liście do żony (tom 2, s. 596). Cenne (i może nawet zaskakujące dla czytelnika nieznającego archiwum) jest wyeksponowanie w tej biografii zjawiska faktycznie bardzo typowego dla ekonomii Herbertowskiego procesu twórczego: myślę tu mianowicie o inwestowaniu ogromnej nieraz energii twórczej w projekty ostatecznie nigdy niezrealizowane, przerwane w rozmaitych stadiach zaawansowania. O tych niespełnionych dziełach Herberta Franaszek pisze wielokrotnie, bywa nawet, że z melancholią (,jaka szkoda, że nie powstało...").

Spośród zjawisk z zakresu „tekstotwórczości”, zauważonych i wzmiankowanych w biografii, bodaj najbardziej spektakularne są dwa. Pierwsze zupełnie mnie nie zaskoczyło - znałem sprawę z własnych kwerend, dla czytelnika wzmianka o niej może być jednak nader ciekawa. Franaszek odkrywa mianowicie, że sławny dziś wiersz Wilki (sławny i niezmiernie spopularyzowany, bo aż do infantylizacji eksploatowany przez popularny dyskurs o „żołnierzach wyklętych") miał początkowo (to jest w swoim brulionie) dynamiczną, zmienną, wielowariantową dedykację. Poeta pracował nad nią długo (dodam od siebie: była ona, sądząc po brulionowym zapisie, bardziej nawet problematyczna, intensywniej przerabiana niż sam tekst): w jej polu pojawiały się różne formacje bojowe z okresu II wojny światowej i z pierwszych lat powojennych, dość powiedzieć, że w jednej z faz swego konstruowania dedykacja 
zwracała się równocześnie do żołnierzy AK i UPA. Innymi słowy, dedykacja brulionowa była polem negocjowania jednego odniesienia do nie tylko różnych, ale skonfliktowanych tradycji i pamięci narodowych. Te brulionowe negocjacje ostatecznie nie przyniosły konkluzji: drukując Wilki na łamach prasowych, następnie zaś w tomiku Rovigo, Herbert opatrywał go dedykacjami (zresztą: dwiema różnymi), niezawierającymi nazw jakichkolwiek, polskich czy niepolskich, formacji bojowych.

W tym miejscu mała zapowiedź: sprawa brulionu tego wiersza jest przeciekawa i nader specyficzna - mówiłem o niej co nieco jeszcze zanim biografia się ukazała ${ }^{18}$, teraz zaś, biografią przynaglony, postanawiam sobie napisać na jej temat obszerniejszy szkic, w którym krytyka genetyczna będzie próbowała szukać wspólnego języka z teorią intertekstualności, studiami nad pamięcią oraz z socjologią odbioru literatury...

Drugi, równie ciekawy casus genetyczny przedstawiony w książce Franaszka był już i dla mnie zaskoczeniem, gdyż przeoczyłem go, choć region archiwum, z którego on pochodzi, penetrowałem dość wnikliwie. Rzeczywiście bardzo frapujące są przemiany małej prozy Epizod w bibliotece (tom 1, s. 209-210), przebiegające dokładnie odwrotnie do przemian utworu Matka mianowicie Herbert coraz mocniej wpisuje tutaj w tekst głośne i aktywne „ja”. Konkretnie, podmiot utworu, w wersjach początkowych tylko przywołujący obraz śmierci młodego poety w powstaniu warszawskim, staje się najpierw jej naocznym świadkiem, wreszcie zaś (i tę wersję znamy z publikacji w tomie Hermes, piesigwiazda) współtowarzyszem broni poległego. Dynamika sytuacji lirycznej i konstrukcji podmiotu in statu nascendi jest tu więc wysoka a psychologizująco-biograficzny komentarz, jakim ten poetologiczny problem opatruje Franaszek, może i ryzykowny (jak zwykle w przypadku orzekania o czymś tak niepochwytnym jako intentio auctoris), ale też ciekawy i zapadający w pamięć.

Dużo zatem w tej biografii pisarza mówi się o samym pisaniu, i bardzo dobrze, a jednak może tu pozostawać uczucie niedosytu, przyjmujące formę twierdzenia, że warto było problem wyeksponować jeszcze mocniej, ująć jeszcze głębiej. Taką uwagę wyczytuję z recenzji Stefana Chwina (skądinąd bardzo wysoko oceniającej książkę Andrzeja Franaszka).

18 M. Antoniuk O czym pamięta(ł) pewien wiersz Herberta? Krytyka genetyczna i praca pamięci, referat wygłoszony na konferencji „Doświadczenie archiwum: pismo, ciało, pamięć”, organizowanej przez Uniwersytet Śląski, Katowice, 6-8 grudnia 2017 roku. 
Ja sam próbowałbym sięgnąć głębiej do dokumentacji medycznej wszystkich tych klinik, o których dr Franaszek wspomina oszczędnie, z rozumnym taktem, bo pasjonuje mnie relacja między chorobą duszy i ciała a talentem - i tekstem. Przeczytałbym też z uwagą kalendarium pobytów Herberta w szpitalach, bo zderzenie twardego języka medycyny z datami narodzin wiersza może sporo powiedzieć o nieodkrytych tajemnicach twórczości. ${ }^{19}$

Tu pozwolę sobie dopowiedzieć: brzmi ten projekt tyleż ciekawie, co niepokojąco. Ciekawie - gdyż zgadzam się, że splot choroby i pisania (szerzej: tworzenia) jest pasjonujący, bynajmniej zaciekawienie nim nie jest (zdarza mi się słyszeć i takie głosy) odruchem jakiejś tabloidowej, goniącej za sensacją, pozbawionej taktu współczesności. Fascynacja związkiem choroby i tworzenia jest przecież mocno wszczepiona w stary, dobry, klasyczny modernizm, ten „wysoki”: to wszak jeden z przewodnich tematów Thomasa Manna, ukochanego pisarza Herberta (by się nie cofać już bardziej, do epok odleglejszych). Zarazem projekt sygnalizowany przez Stefana Chwina musi niepokoić - ponieważ faktycznie pojawia się tu pytanie o etyczne granice, o poszanowanie intymności człowieka, któremu przydarzyło się, zarazem, tworzyć i chorować, a który, już nie żyjąc, wydany jest niejako na łup ciekawości, strojnej w rozmaite metodologiczne przebrania. Ale też wcale nie jest oczywiste, na ile taki projekt - czytania "dokumentacji procesu twórczego" wraz ze specjalistyczną, szpitalną „dokumentacją procesu chorobowego" byłby produktywny. W przypadku Herberta chronologie szpitalnych pobytów i chronologie procesu twórczego niełatwo na siebie nałożyć; zakładając nawet, że da się precyzyjnie, co do dnia, odtworzyć daty pobytów w szpitalach na podstawie, przykładowo, wypisów (nie wiem, w jakiej mierze takie dokumenty są zachowane w archiwum Herberta, nigdy tego nie sprawdzałem), to trudniejsza już sprawa z równie dokładnym datowaniem aktów twórczych. Wiele Herbertowskich brulionów dat zwyczajnie nie posiada, tam zaś, gdzie datacja (zwykle dokładna: dzień, miesiąc, rok) się pojawia, tam jest ona nieuchronnie

19 Odnoszę się do recenzji dorobku habilitacyjnego, dostępnej na stronie Centralnej Komisji ds. Stopni i Tytułów. Zdaję sobie, rzecz jasna, sprawę, że recenzje wystawiane w postępowaniach awansowych to de facto teksty reprezentujące inny gatunek pisarski, zasadniczo różny od recenzji krytycznoliterackich. Są to jednak również teksty funkcjonujące w jawnym, otwartym dyskursie, współbudują zatem recepcję książek naukowych. A uwaga zawarta w cytowanej recenzji habilitacyjnej zainteresowała mnie tak bardzo, że odnieść się do niej wydało mi się koniecznym. 
podejrzana, niepewna, gdyż Herbert nagminnie mylił daty (w czym akurat nie ma żadnej strategii kamuflażu, lecz efekt, tak typowego dla tego poety, „skyptualnego roztargnienia"). A wreszcie, odsunąwszy na bok poprzednie uwagi: w tropieniu, nawet bardzo subtelnym, związków choroby i pisania, łatwo o rozmaite uroszczenia. Wiele rodzi się tu wątpliwości już nie etycznych nawet, a po prostu profesjonalnych, metodologicznych. Chociażby taka: czy, jak to ujmuje Chwin, „twardy język medycyny” jest aż tak twardy, że można na nim oprzeć rzeczywiście prawdziwy opis kondycji psychofizycznej podmiotu (czy tego akurat języka nie dotyczy w żadnej mierze kryzys reprezentacji, referencji, czy nie ma on swoich klisz, skorup nomenklatury, w które zastyga, miast chwytać migotliwą rzeczywistość)?

Mnożę wątpliwości, trochę z przekonania, trochę dla dramaturgii, ale kwestia tu poruszana żywo mnie obchodzi. Komentarz Stefana Chwina, odniesiony bezpośrednio do pracy Andrzeja Franaszka, uświadamia mi czy przypomina, że we współtworzonej przeze mnie Pracowni Herberta trop podpowiadany przez gdańskiego badacza podjęty jest w bardzo niewielkiej mierze. Może szkoda? Trochę w duchu nadrabiania zaległości wywołuję więc teraz casus wiersza Wstyd, drukowanego w tomie Rovigo, a zaczynającego się od słów:

Kiedy byłem bardzo chory opuścił mnie wstyd bez sprzeciwu odsłaniałem obcym rękom wydawałem obcym oczom biedne tajemnice mego ciała

Wkraczali we mnie ostro powiększając poniżenie ${ }^{20}$

Otóż brulion tego wiersza ma aż dwie daty - 21 lipca 1991 oraz 21 sierpnia 1991 roku - z których rzeczywista jest (w najlepszym razie!) tylko jedna (różne argumenty tekstologiczno-materialne za tym przemawiają, nie mogę tezy rozwijać, gdyż spuchłaby w dygresję). Wertuję zatem biografię autorstwa Andrzeja Franaszka; w tomie 2 na stronach 672-675 znajduję opis letnich miesięcy roku 1991. Nie jest to opis w pełni precyzyjny (jakoż biograf-narrator, zmagający się tu z mnogością i nieczytelnością sprzecznych przesłanek, zastrzega: „Trudno do końca odtworzyć chronologię”), jeśli jednak dobrze rozumiem, zarówno lipcowa, jak i sierpniowa data brulionu oznacza, że wiersz powstawał w czasie pobytu poety w szpitalu. To znaczy albo w psychiatrycznej klinice w Neuilly-sur-Marne pod Paryżem, albo w paryskim (ale już 
„zwykłym”, takim „od ciała”) Szpitalu Świętego Ludwika (Herbert przechodził w tym czasie ostry kryzys zdrowotny, związany z infekcją i, być może, jakimś nerwowym załamaniem). Jakkolwiek by było, kartka brulionu zdaje się nam mówić, że wiersz o upokorzeniu pacjenta powstaje nie z perspektywy całkowicie już ex post (co sugeruje pierwszy wers z jego czasem przeszłym: „kiedy byłem bardzo chory”), lecz wciąż jeszcze in medias res, z wnętrza doświadczenia. Ale ta sama kartka ujawnia coś jeszcze: mianowicie pełną koncentrację piszącego, tworzącego człowieka, który po prostu jest tu poetą - układaczem słów. Herbert podmienia wyrazy, dodaje, usuwa, panuje nad formą, jest w swoich działaniach tekstotwórczych precyzyjny (żadnych różnic, jak chodzi o zawiadowanie czynnościami twórczymi w stosunku do brulionów z okresów „zdrowia”). Być może więc tym, co ofiarowuje nam lektura tego wiersza w jego szpitalnym brulionie (a nie w tomikowym druku), jest bardziej bezpośrednie (przejmujące) świadczenie o człowieku, który trwa w dramatycznym rozdwojeniu: równocześnie panuje nad pismem, kartką, formą tekstu (o skuteczności tego panowania mówi materialność rękopisu) i nie panuje nad własnym ciałem, ciałem, którego intymności nie jest w stanie bronić, z którego w pewnym sensie zostaje wywłaszczony przez lekarskie procedury (o tym mówi „sens” wiersza).

\section{Co dalej?}

Zmierzam ku puencie, wcześniej tylko ostatnia już uwaga: książka Andrzeja Franaszka może inspirować do dalszych eksploracji, rozpoznań, badań. Mimo ogromnej pracy archiwalnej, wykonanej przez krakowskiego literaturoznawcę, w biografii Herberta wciąż pozostają obszary czy wątki domagające się kontynuowania studiów archiwalno-dokumentacyjnych - jednym z nich jest, jak się zdaje, kwestia funkcjonowania autora Pana Cogito i Drugiego pokoju w społeczno-kulturowym kontekście Niemiec Zachodnich.

Myślę też jednak o innej jeszcze stymulacji: obfitość niepublikowanych materiałów, które cytuje biograf, każe wciąż stawiać pytania o edycje ineditów czy (czego dotąd właściwie nie podejmowano) edycje genetyczne ( $\mathrm{tj}$. takie, które pokazują sam proces dochodzenia do tekstu). Warto przemyśleć sprawę opublikowania przynajmniej kilku utworów omawianych przez Andrzeja Franaszka, takich np. jak dramat Przewodnik - w biografii znajdziemy jego streszczenie oraz uwagę, że stanowi on „swego rodzaju glosę do lekcji historii przedstawionych w Barbarzyńcy.... Od siebie dodam, że tekst ten jest właściwie kompletny, jak najbardziej edytowalny (istnieje w wersji nie 
tylko rękopisowej, ale i maszynopisowej)... Bez wątpienia nowej, w pełni tego słowa znaczeniu krytycznej edycji wymaga esej Lekcja łaciny, którego koleje losu przybliża nieco biografia Franaszka, a którego tekstologię - dość mocno zawikłaną - próbował, jak sądzę przekonująco, zarysować Wojciech Gruchała w jednym z rozdziałów Pracowni Herberta... W przypadku tego utworu zasadne byłoby wydanie genetyczne (choćby selektywne, uwzględniające część archiwalnego dossier), pokazujące „w działaniu” różne wersje z trudem komponowanego eseju. Wreszcie pewien pomysł edytorski - choć dotyczący już nie twórczości Herberta - podrzuca na kartach biografii sam Franaszek: chodziłoby mianowicie o zrealizowanie Herbertowskiego projektu antologii poezji europejskiej (zob. tom 2, s. 594). Takich możliwości do rozważenia, podsuwanych przez biografię jest więcej... i tylko szkoda, że piszę te słowa po ukazaniu się ostatniego numeru „Zeszytów Literackich”, pisma, które dla publikacji Herbertowych ineditów zrobiło wiele (i z którym miałem zaszczyt współpracować przy edycji kilku wcześniej nieznanych opowiadań Herberta).

Trzeba jeszcze dodać, że książka Franaszka zawiera również w sobie pewną odległą, ale frapującą zapowiedź wydawniczą. Otóż do jej tomu 2 dołączono krótkie, niewielkie kalendarium życia i twórczości Zbigniewa Herberta w opracowaniu Henryka Citki. Jak czytamy, jest to jedynie próbka, całość ma być obszerna i gotowa na rok 2024, czyli na stulecie urodzin autora Pana Cogito. Oby ten plan został zrealizowany.

\section{Tytułem podsumowania}

Jeśli nie powiedziałem tego dość wyraźnie, dopowiadam teraz: podoba mi się książka Andrzeja Franaszka. Cenię ją i uważam za pozycję ważną zarówno dla literaturoznawców, jak i czytelników interesujących się literaturą polską XX wieku bez profesjonalnych zobowiązań. Najkrócej: opiera się ta książka na bardzo rzetelnej pracy kwerendowej, napisana jest znakomicie, uwzględnia (o tym nie wspomniałem, więc dodaję „rzutem na taśmę”) socjologiczno-kulturowe konteksty życia i twórczości Zbigniewa Herberta (znajdziemy w niej ciekawe portrety środowisk intelektualno-twórczych, także zagranicznych i nie tylko polskich-emigracyjnych, w których poeta-nomada pojawiał się, w których, zwykle przejściowo, funkcjonował).

Wielostronna, wyważona, prowadzona z, tak bym to ujął, krytyczną sympatią dla postaci głównego bohatera - jest ta biografia historycznoliterackim dokonaniem dużej wartości i miary. 


\section{Abstract}

\section{Mateusz Antoniuk}

JAGIELLONIAN UNIVERSITY (CRACOW)

Writing Herbert: Andrzej Franaszek's New Biography

Antoniuk discusses Andrzej Franaszek's biography of Zbigniew Herbert (Herbert; vol. 1: Niepokój [Unrest], vol. II: Pan Cogito [Mr. Cogito], Cracow 2018). The article opens with a discussion of Franaszek's strategies as a biographer, then turns to the question of the main aspect of the portrait that emerges from his book, and concludes with detailed comments from the perspective of a Herbert scholar familiar with his archive. The article also includes a marginal discussion on biographical writing.

\section{Keywords}

biography, archive, creative process, Zbigniew Herbert 